\title{
The H-2A Program and Immigration Reform in the United States ${ }^{1}$
}

\author{
Berdikul Qushim, Zhengfei Guan, and Fritz M. Roka²
}

\section{Introduction}

The Immigration and Nationality Act (INA) of 1952 authorized a nonimmigrant visa category, known as $\mathrm{H}-2$, for foreign agricultural and nonagricultural workers to come to the United States and perform temporary services. The Immigration Reform and Control Act (IRCA) of 1986 amended the INA of 1952 by dividing the $\mathrm{H}-2$ program into two parts: $\mathrm{H}-2 \mathrm{~A}$ for agricultural workers and $\mathrm{H}-2 \mathrm{~B}$ for nonagricultural workers. The Employment and Training Administration (ETA) of the United States Department of Labor (US-DOL) and United States Citizenship and Immigration Services (USCIS) of the Department of Homeland Security (DHS) administer both the H-2A and $\mathrm{H}-2 \mathrm{~B}$ programs. The United States DOL describes the $\mathrm{H}-2 \mathrm{~A}$ program as "a means for agricultural employers who anticipate a shortage of domestic workers to bring in nonimmigrant foreign workers to the United States to perform agricultural labor or services of a temporary or seasonal nature" (US-DOL 2016).

The specialty crop industries within the United States are labor intensive and have been increasingly dependent on a large number of foreign-born immigrants. The recent debates by Congress over immigration reform have highlighted the fact that a majority of agricultural workers are not authorized to work in the United States. More than half (52\%) of the crop workers surveyed in the 2009/10 National

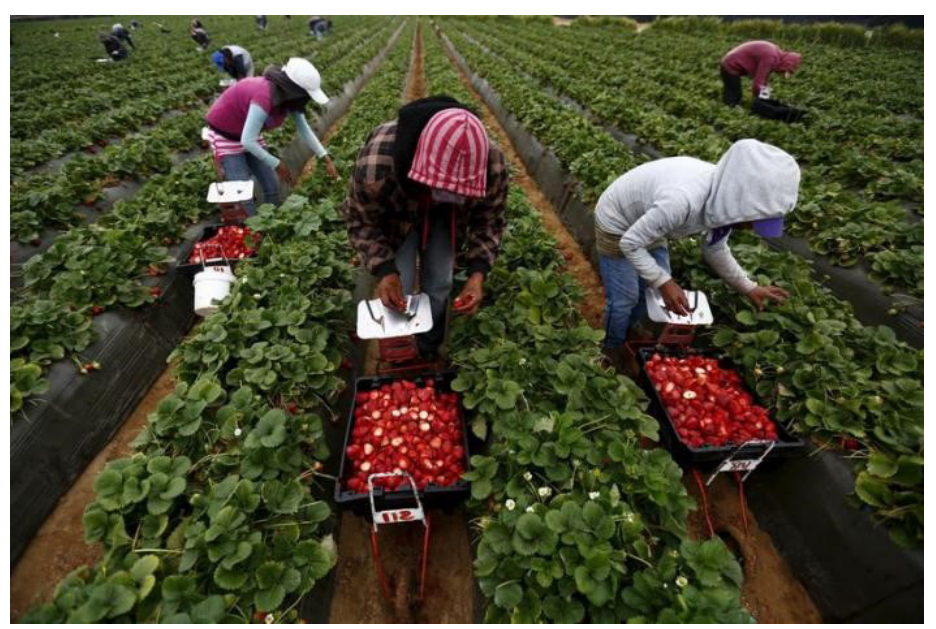

Credit: USDA

Agricultural Workers Survey (NAWS) self-reported that they were not legally authorized to work in the United States, up 3\% from the $2007 / 08$ NAWS. Of these workers, $90 \%$ were working in specialty crops. A recent study in the Florida strawberry industry found that half the growers believed that unauthorized workers accounted for $90 \%$ of the industry work force; only one-fifth of the growers believed that the unauthorized workers were less than 70\% (Guan et al. 2015). Another study found evidence of labor shortages among farm labor contractors who were engaged in production practices, including soil preparation, planting, cultivating, and harvesting of other fruit and vegetable crops (Hertz and Zahniser 2013). Labor shortages are a

1. This document is FE1029, one of a series of the Food and Resource Economics Department, UF/IFAS Extension. Original publication date March 2018. Visit the EDIS website at http://edis.ifas.ufl.edu.

2. Berdikul Qushim, postdoctoral research associate; Zhengfei Guan, assistant professor, Food and Resource Economics Department, UF/IFAS Gulf Coast Research and Education Center, Wimauma, FL 33598; and Fritz M. Roka, associate professor, Food and Resource Economics Department, UF/IFAS Southwest Florida Research and Education Center, Immokalee, Florida 34142.

The Institute of Food and Agricultural Sciences (IFAS) is an Equal Opportunity Institution authorized to provide research, educational information and other services

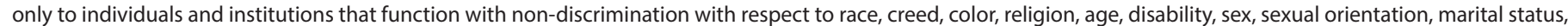

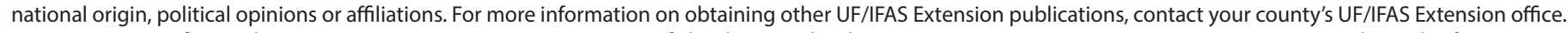
U.S. Department of Agriculture, UF/IFAS Extension Service, University of Florida, IFAS, Florida A \& M University Cooperative Extension Program, and Boards of County Commissioners Cooperating. Nick T. Place, dean for UF/IFAS Extension. 
major threat to the industry and could lead to a significant amount of fruit being abandoned in the fields at the peak of harvesting times. In addition, the Guan et al. (2015) survey revealed that many strawberry growers could not depend on American workers to do agricultural labor work because they complained "Americans don't want to do labor work" in the field. To protect against disruptions in the farm labor supply, many growers are turning to the $\mathrm{H}-2 \mathrm{~A}$ program to import foreign guest workers. The $\mathrm{H}-2 \mathrm{~A}$ program, however, is considered expensive and cumbersome (Guan et al. 2015).

\section{H-2A Program: Temporary Agricultural Workers}

The $\mathrm{H}-2 \mathrm{~A}$ program allows agricultural employers who anticipate a shortage of domestic workers to petition the US-DOL for nonimmigrant foreign workers to be brought into the United States for temporary employment. An H-2A petition for temporary employment of foreign workers is for a defined period of time not longer than one year.

Two conditions must be met before the US-DOL Employment and Training Administration's (ETA) Office of Foreign Labor Certification will approve an H-2A petition. First, the employer must demonstrate that there are insufficient numbers of "qualified" US workers available to perform the agricultural jobs for which foreign workers are being requested. "Qualified" workers are defined as those individuals who are willing and able to do the job. Specific job experience may not be necessary. Second, the employer must also demonstrate that the importation of foreign workers will not adversely affect the earnings and working conditions of similarly employed US workers. The US-DOL's Office of Foreign Labor Certification requires that employers must initially try to recruit US workers to fill positions and must continue to recruit US workers even after $\mathrm{H}-2 \mathrm{~A}$ workers are recruited.

The petition process starts when an employer files ETA Form 790, also known as the Job Order, with the State Workforce Agency (SWA). Florida's SWA is the Department of Economic Opportunity. The Job Order specifies the number of workers needed to perform specific jobs on specific crops over a defined period of time in the area of intended employment. ETA Form 790 is filed between 60 and 75 days before the date of need for workers. After the SWA approves ETA Form 790, employers must also complete an $\mathrm{H}-2 \mathrm{~A}$ application for temporary employment certification or ETA Form 9142A and submit it together with ETA Form 790 along with all supporting documentation to the US-DOL-ETA National Processing Center (NPC) in Chicago no less than 45 days prior to the employer's date of need. Officials at the NPC establish the extent to which an employer will advertise for domestic workers beyond the area of intended employment. In most cases, three adjoining states are chosen as potential areas for active recruitment of domestic workers.

Once ETA Form 9142A has been approved, USCIS officials are notified through Form I-129, a petition for nonimmigrant workers. In the meantime, employers are recruiting foreign workers and once they are notified that their petitions have been certified by both US-DOL-ETA and USCIS, appointments for worker interviews are arranged at a US consulate. During the interview, workers are vetted against US databases and questioned about their understanding of the terms and conditions of the $\mathrm{H}-2 \mathrm{~A}$ contract they are about to sign. Once approved, the workers are given $\mathrm{H}-2 \mathrm{~A}$ visas, and they board buses or other forms of transportation to begin their journey to the employer's housing facility designated on the ETA Form 790.

In recent years, interest in hiring $\mathrm{H}-2 \mathrm{~A}$ workers has increased, and more and more growers are turning to the $\mathrm{H}-2 \mathrm{~A}$ program due to labor shortages (Guan et al. 2015). In addition to paying for all the petition, visa, recruitment, transportation, and housing costs, an $\mathrm{H}-2 \mathrm{~A}$ employer must pay a significantly higher minimum wage, known as the adverse effect wage rate (AEWR), so that the employment of foreign guest workers does not adversely affect wages or earnings of domestic workers performing similar tasks. As of January 1, 2017, the AEWR in Florida was $\$ 11.12$ as compared to the state minimum wage of $\$ 8.10$. Moreover, the $\mathrm{H}-2 \mathrm{~A}$ guest worker program requires employers to offer the same benefits to domestic workers doing similar tasks on the farm.

\section{H-2A Program: Expansion}

The recruitment of $\mathrm{H}-2 \mathrm{~A}$ workers has increased significantly in recent years, most notably in Florida. The total number of certified $\mathrm{H}-2 \mathrm{~A}$ workers across the United States increased from 79,011 in 2010 to 165,420 in 2016, an increase of 109\% (Table 1). In Florida, certified H-2A positions have increased more than fourfold, from 4,432 in 2010 to 22,828 in 2016. As a percentage of the national total, Florida's share of $\mathrm{H}-2 \mathrm{~A}$ workers increased from $5.6 \%$ to nearly $14 \%$ between 2010 and 2016. The average number of workers per application has fluctuated between 80 and 100 (Table 1). The rule that the "area of intended employment" can be no greater than a 60 -minute driving radius from the employer's H-2A housing facility applies only to 
farm labor contractors (FLCs); growers who hire $\mathrm{H}-2 \mathrm{~A}$ are not affected by the rule.

\section{US Immigration Reform}

The latest immigration legislation in the United States was the 1986 Immigration Reform and Control Act. Between 2006 and 2013, both the US Senate and US House proposed some immigration legislations that included enforcement, legalization of unauthorized immigrants, and an expansion of the guest worker program. Illegal immigration has been a focus of the Trump administration, which has called for mass deportations of all undocumented workers in the United States. This policy has appealed to a large conservative constituency of his election campaign. However, some argue that large-scale deportation of illegal immigrants could be detrimental to the US economy and that the United States cannot afford to suddenly lose the majority of the immigrants who work without legal documents in the agriculture, landscaping, construction, hotel, and other hospitality industries. According to the USDA Economic Research Service study (Zahniser et al. 2012), a large reduction in the number of unauthorized workers will result in a long-run reduction in output and exports for both agriculture and the broader economy. Other studies in the literature have also confirmed the resulting detrimental effects of enforcing current immigration law on agriculture (O'Brien et al. 2014). The immigration reform regarding illegal immigration touches on multiple dimensions: economic, legal, and political. Whatever policy eventually prevails, it will be a balance of interests of different groups.

Labor shortages, legal risks of employing undocumented workers, and uncertainties associated with the political environment seemed to have driven the increasing adoption of the $\mathrm{H}-2 \mathrm{~A}$ guest worker program. However, the program has received criticisms from both farmworker advocates and critics of immigration reform. Farmworker advocates have long viewed the $\mathrm{H}-2 \mathrm{~A}$ program with grave suspicion. Not only do they argue that domestic farmworkers should be paid higher wages and offered better working conditions, they fear that many foreign guest workers will be subject to abusive situations because they are bound to a single employer for the duration of the H-2A contract. Critics of immigration reform worry that a number of $\mathrm{H}-2 \mathrm{~A}$ workers will abandon their contracts and become part of the wider illegal immigrant community. Nevertheless, there are benefits associated with guest worker programs. Zahniser et al. (2011) showed that agricultural employers would benefit from expanded use of $\mathrm{H}-2 \mathrm{~A}$ guest worker program, particularly the labor-intensive agricultural sectors. Their simulation model results indicated that increasing the number of guest workers would lead to increases in the production of crops, and that decreasing the supply of unauthorized workers would lead to a decreases in crop production. Labor shortages have made immigration reform a critical issue for agriculture, and will have significant implications for the labor-intensive specialty crop industry.

\section{Concluding Remarks}

Despite various complaints from agricultural employers about the $\mathrm{H}-2 \mathrm{~A}$ guest worker program, the adoption of the $\mathrm{H}-2 \mathrm{~A}$ program has been increasing rapidly in the last few years. This is largely driven by labor shortages, legal concerns, and political uncertainties. Agricultural employers would benefit from expanded use of Guest Worker Programs or the $\mathrm{H} 2 \mathrm{~A}$ guest worker program (Zahniser et al. 2011, 2012; O’Brien et al. 2014). Increasing the employment of temporary nonimmigrant farmworkers or $\mathrm{H}-2 \mathrm{~A}$ workers could provide a viable solution. With employers expressing dissatisfaction with the costs of employing foreign $\mathrm{H}-2 \mathrm{~A}$ workers, more research is needed to assess the tradeoff between the potential "adverse effects" of the H-2A workers on the domestic labor market and the economic contribution of the program to US agriculture, which will provide justifications for reforms of the $\mathrm{H}-2 \mathrm{~A}$ program, or immigration reform in general. In particular, decreasing costs and bureaucratic challenges associated with the $\mathrm{H}-2 \mathrm{~A}$ guest worker program and making the program more economically feasible will increase the adoption of the program and help address labor shortages in US agriculture.

\section{References}

Guan, Z., F. Wu, F.M. Roka, and A. Whidden. 2015. "Agricultural Labor and Immigration Reform." Choices 30(4): $1-9$.

Hertz, T., and S. Zahniser, 2013. "Is There a Farm Labor Shortage?" American Journal of Agricultural Economics 95(2): 476-81.

O'Brien, P., J. Kruse, and D. Kruse. 2014. Gauging the Farm Sector's Sensitivity to Immigration Reform via Change in Labor Costs and Availability. WAEES. Washington, DC: American Farm Bureau Federation.

US-DOL (United States Department of Labor). 2016. Employment Law Guide: Work Authorization for Non-US Citizens: Temporary Agricultural Workers (H-2A Visas). US-DOL, Washington, DC. https://webapps.dol.gov/elaws/ elg/taw.htm. 
Zahniser, S., T. Hertz, P. Dixon, and M. Rimmer. 2011.

"Immigration Policy and Its Possible Effects on US Agriculture and the Market for Hired Farm Labor: A Simulation Analysis. American Journal of Agricultural Economics 94(2):

477-482.

Zahniser, S., T. Hertz, P. Dixon, and M. Rimmer. 2012. "Immigration Policy and Its Possible Effects on US Agriculture." Amber Waves. (USDA-ERS, Washington, DC). https://www.ers.usda.gov/amber-waves/2012/june/ immigration-policy/ 
Table 1. Certified H-2A applications and positions in the United States and Florida, 2010-2016.

\begin{tabular}{|c|c|c|c|c|c|c|c|}
\hline Fiscal Year (FY) & 2010 & 2011 & 2012 & 2013 & 2014 & 2015 & 2016 \\
\hline & \multicolumn{7}{|c|}{ Certified H-2A Applications } \\
\hline United States & 6,988 & 7,000 & 7,845 & 8,118 & 9,152 & 9,962 & 8,297 \\
\hline \multirow[t]{2}{*}{ Florida } & 51 & 54 & 78 & 108 & 169 & 192 & N/A \\
\hline & \multicolumn{7}{|c|}{ Certified H-2A Positions } \\
\hline United States & 79,011 & 77,246 & 85,248 & 98,821 & 116,689 & 139,832 & 165,420 \\
\hline Florida & 4,432 & 5,741 & 6,945 & 10,051 & 13,544 & 17,942 & 22,828 \\
\hline Florida \% Certified Positions & $5.61 \%$ & $7.43 \%$ & $8.15 \%$ & $10.17 \%$ & $11.61 \%$ & $12.83 \%$ & $13.8 \%$ \\
\hline Florida H-2A Workers per Application & 87 & 106 & 89 & 93 & 80 & 93 & N/A \\
\hline Florida Adverse Effect Wage Rate $(\$ / \mathrm{hr})$ & $\$ 9.20$ & $\$ 9.50$ & $\$ 9.54$ & $\$ 9.97$ & $\$ 10.26$ & $\$ 10.19$ & $\$ 10.70$ \\
\hline
\end{tabular}

